\title{
Modal analysis and geochemistry of two sandstones of the Bhander Group (Late Neoproterozoic) in parts of the Central Indian Vindhyan basin and their bearing on the provenance and tectonics
}

\author{
Apurba BANERJEE ${ }^{1,2, *}$ and D M BANERJEE ${ }^{1, * *}$ \\ ${ }^{1}$ CAS in Geology, Chattra Marg, University of Delhi, Delhi 110 00\%, India. \\ ${ }^{2}$ Present Address: Geological Survey of India, Ranchi 834 009, India. \\ *e-mail: apurbageol@yahoo.co.uk \\ **e-mail: dhiraj1942@gmail.com
}

\begin{abstract}
The Neoproterozoic Bhander Group in the Son Valley, central India conformably overlying the Rewa Group, is the uppermost subdivision of the Vindhyan Supergroup dominantly composed of arenites, carbonates and shales. In Maihar-Nagod area, a thick pile of unmetamorphosed clastic sedimentary rocks of Bhander Group is exposed, which provides a unique opportunity to study Neoproterozoic basin development through provenance and tectonic interpretations. The provenance discrimination and tectonic setting interpretations are based on modal analysis and whole rock geochemistry. The average framework composition of the detrital sediments composed of quartz and sedimentary lithic fragments are classified as quartz arenite to sublitharenite. The sandstone geochemically reflects high $\mathrm{SiO}_{2}$, moderate $\mathrm{Al}_{2} \mathrm{O}_{3}$ and low $\mathrm{CaO}$ and $\mathrm{Na}_{2} \mathrm{O}$ type arenite. The high concentration of HFSE such as $\mathrm{Zr}$, Hf, and $\mathrm{Th} / \mathrm{Sc}, \mathrm{Th} / \mathrm{U}$ ratios in these sandstones indicate a mixed provenance. The chondrite normalized REE pattern shows moderate to strong negative Eu anomaly which suggests that major part of the sediments were derived from the granitic source area. The sandstone tectonic discrimination diagrams and various geochemical plots suggest that the provenance of the lower and upper Bhander sandstone formations was continental interior to recycled orogen.
\end{abstract}

\section{Introduction}

Sandstone compositions have been widely used by sedimentologists during the past few decades to decipher the provenance and tectonic setting of source areas (Pettijohn et al 1972; Dickinson and Suczek 1979; Dickinson 1982, 1985, 1988; Dickinson et al 1983; Potter 1986). Provenance in turn is important to understand the geologic history, tectonic setting and crustal evolution during the deposition of sediments. The Neoproterozoic Bhander Group of sedimentary rocks exposed in central India consists of a wide variety of arenites, carbonates and shales and therefore provide a unique opportunity for interpreting the tectonic setting of the Precambrian Vindhyan sedimentary basin. The petrography of the Bhander sandstones has been only partially studied (Basumallick 1962; Singh 1976; Bose and Chaudhuri 1990; Bhattacharyya 1993). A detailed analysis will add knowledge to our understanding of relationship between the sandstone composition and the tectonic settings of the source terrain.

Several workers have tried to document the relationship between the framework mode of the sandstone, the major and trace element geochemistry, the provenance type and the tectonic setting of a sedimentary basin (Schwab 1975; McLennan et al 1983; Condie et al 1991; Cullers 1994). It is however true that framework grains, on its own,

Keywords. Bhander Group; modal analyses; provenance; geochemistry; recycled orogen. 


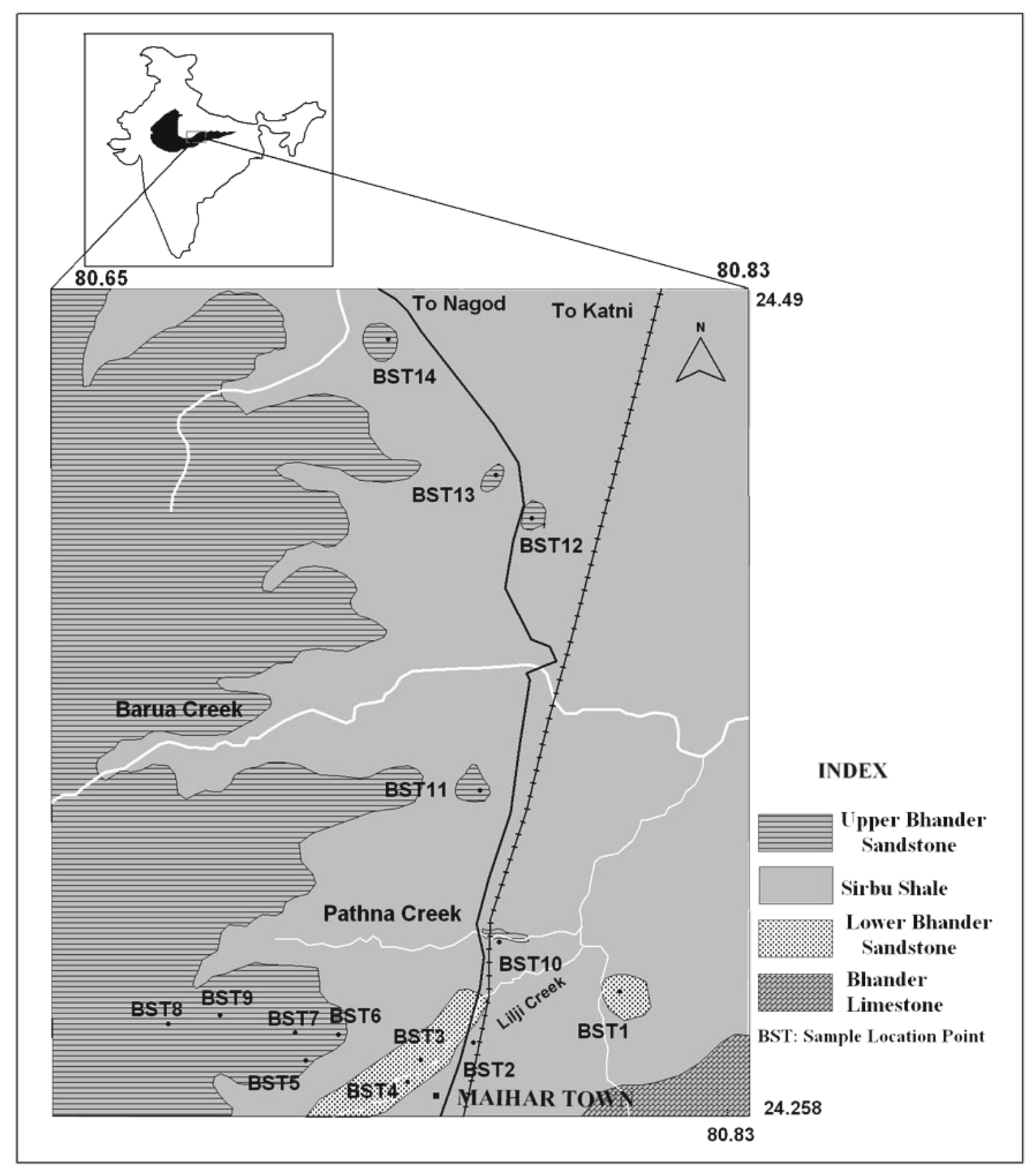

Figure 1. Simplified local geological map of the Maihar-Nagod area, Son Valley, central India.

sometimes fail to reflect the true crustal setting, because the sediment particles get modified during diagenesis and weathering. Hence, a judicious combination of petrographic data and chemical analyses of sedimentary rocks provide important information about the characteristics of the provenance as well as tectonic setting. In this paper, we have used the modal composition and the geochemical characteristics of the clastic units of the Bhander Group exposed near Maihar township in central India (figure 1) for interpreting the nature of the provenance. The major elements as well as various immobile trace elements like La, Th, $\mathrm{Zr}$, Hf (enriched in silicic rocks) and $\mathrm{Sc}, \mathrm{Cr}$ and Co (enriched in basic rocks) have been extensively used to understand and estimate the relative contributions of the silicic and basic rocks to the sandstones representing different tectonic environments (Bhatia and Crook 1986; Condie 1993). The provenance in turn, is important to understand the geologic history, tectonic setting and crustal evolution during the deposition of sediments. The relative REE patterns and the extent and nature of Eu anomalies have been widely used 
in the provenance discrimination studies (Taylor and McLennan 1985). Because there are no selective losses of any REE during weathering, Eu anomalies could not have been produced by weathering alone. In addition, we present here the first ever reported trace and rare earth elemental geochemical data for the sandstones of the Bhander Group.

\section{Geologic setting}

Rocks comprising the Vindhyan Supergroup formed in a spectacular crescent-shaped intracratonic central Indian Proterozoic basin and stratigraphically classified under four subdivisions namely the Semri, the Kaimur, the Rewa and the Bhander each with a group status. The Vindhyan basin has Bundelkhand Granite to the north limiting its northward extension. The SonNarmada lineament with metamorphic rocks of the Mahakoshal group restricts its extension to the south and the northwestern part of the basin is truncated by the rocks believed to be equivalent of the Aravalli Supergroup (Auden 1933). The sedimentary rock piles conformably overlying the Rewa Group constitute the uppermost subdivision of the Vindhyan Supergroup and are known as the Bhander Group named after the Bhander hill range. The Bhander Group is exposed in the Maihar-Nagod area of central India, represents a thick sedimentary pile made up of sandstone, limestone and shale and constitutes the largest proportion of the total exposures of the Vindhyan rocks. This group shows extensive lateral facies variation and consists of five identifiable formations namely the Ganurgarh Shale, the Nagod Limestone, the Lower Bhander Sandstone, the Sirbu Shale and the Upper Bhander Sandstone in the Maihar-Nagod sector, the area of the present study.

In view of the age of Vindhyan rocks (Crawford and Compston 1970) dated the UBS by K/Ar method, which gave the age as $550 \mathrm{Ma}$. Srivastava and Rajgopalan (1988) dated the LBS by FT method and suggested an age of $625+25 \mathrm{Ma}$. According to Ray et al (2002), the ${ }^{87} \mathrm{Sr} /{ }^{86} \mathrm{Sr}$ ratio of Bhander Limestone is consistent with Late Neoproterozoic age (650-770 Ma), while Chakrabarty et al (2007) dated the porcellanites of the Semri Group by using the Nd isotope technique and suggested $\sim 1.6 \mathrm{Ga}$ age. Stromatolite assemblage in the carbonate units and trace and dubiotraces in the siliciclastic rocks of the Bhander Group indicated a Late Riphean (Neoproterozoic) age for these rocks (Kumar 1976; Rao et al 1977; Chakrabarti 1990). Recent paleomagnetic study combined with detrital zircon geochronology (Malone et al 2008) has painted an altogether different picture by suggesting 1000-1070 Ma age range for the Upper Vindhyans which contradicts all previous estimates and assumptions. Assuming this age estimate to be correct, the Upper Vindhyan succession becomes time contemporaneous to the sedimentary sequence of the Raipur Group in Chattisgarh basin of central India (Basu et al 2008).

The sandstone in succession occurs at two levels representing the Lower (LBS) and Upper formations (UBS). While the lowermost unit of the Bhander Group, the Ganurgarh Shale is most impersistent over the area, the LBS is a comparatively better exposed unit but often mistaken for the overlying Sirbu Shale which is typically brown to greenish in colour and therefore helps in separating it from the shaly units of the LBS. It is believed that the lenticular stromatolitic carbonate bed within the Sirbu Shale unit separates the shale unit from the sandstone. The LBS is made up of hard, fine grained, dirty white, highly indurated arenites and can be petrographically classified as sublitharenite. The subrounded well sorted quartz grains reflect prolonged transportation and reworking on a stable seafloor. The UBS, on the other hand, occurs as a persistent horizon occupying the top-most position in the Vindhyan stratigraphy. It occupies an almost entire axial position of the Vindhyan basin and consists of thick, mildly deformed sequence of terrigenous rock and forms steep vertical escarpments. The UBS is less indurated than the LBS and is moderately hard, reddish in color and attain up to 50 to $60 \mathrm{~m}$ thickness in some sections. Petrographically, the sandstone is classified as quartz arenite to sublitharenite. The contact between the Sirbu Shale and the UBS is gradational indicating uninterrupted sedimentation, although the contact is often marked by a stromatolite bearing carbonate unit of variable thickness. The blanket type deposition with characteristic primary sedimentary features has led some researchers to interpret tidal flat to lagoon type depositional environment for the sandstone formations (Chanda and Bhattacharya 1974; Singh 1976) while Bhattacharya et al (1980) and Bose and Chaudhuri (1990) inferred coastal playas with prominent influence of storm in the depositional basin of LBS (Bose et al 2001) and the UBS was interpreted as eolian deposit by Bose et al (1999).

\section{Methods}

Thirty representative arenite samples were collected from 14 well constrained stratigraphic lithologs near Maihar township (figure 1) representing the Lower Bhander Sandstone (LBS) and the Upper Bhander Sandstone (UBS). Modal 
Table 1. A generalized stratigraphic scheme of Maihar, Satna and Nagod area of the Son Valley, central India after Auden (1933) and Bhattacharyya (1993).

Bhander Group
Upper Bhander Sandstone Formation (UBS)
Sirbu Shale Formation
Lower Bhander Sandstone Formation (LBS)
Bhander Limestone Formation
Ganurgarh Shale Formation

analyses of 57 samples were carried out using Leica Qwin V3 Image Analyzer. In each thin section, 500 grains were counted according to the Gazzi-Dickinson method (Ingersoll et al 1984). Framework constituents were determined using the nomenclature advocated by Dickinson and Suczek (1979); Dickinson et al (1983) and Dickinson (1985). This includes identification and recording the amount of monocrystalline quartz $(\mathrm{Qm})$, polycrystalline quartz $(\mathrm{Qp}),(\mathrm{Qm}$ and $\mathrm{Qp}$ make together makes the total quartz Qt), feldspar (F), lithic sedimentary and metasedimentary clasts (Ls) and lithic volcanic clasts (Lv), (Ls and Lv constitute together with lithic clastics L). Result of the point count is given in table 2 and the ternary plots are shown in figures $3-6$.

Major element concentrations were determined with X-ray Fluorescence Spectrometer. Fused beads of the samples were used for major element analyses while pressed pellets were used for analyzing Na. The data obtained with the in-house NGRI reference standards that were analyzed during the same runs as unknown samples show that the accuracy of the determinations were better than $95 \%$. Loss on ignition (LOI) was estimated by firing the sample at $1000^{\circ} \mathrm{C}$. Trace and rare earth element concentrations were determined by ICP-mass spectrometry (ICP-MS) following the standard procedure (Balaram et al 1999). Rock standard GSR-4 was used and analyzed in triplicate so as to restrict the maximum error to $5 \%$ for major, trace and rare earth elements and $7 \%$ for $\mathrm{Na}_{2} \mathrm{O}$ and $\mathrm{K}_{2} \mathrm{O}$.

\section{Petrography}

\subsection{Lower Bhander Sandstone Formation (LBS)}

\subsubsection{Modal analysis}

Nearly $70 \%$ of the total framework grains comprise quartz and lithic fragments. These grains are subangular to subrounded, moderately sorted and show textural maturity (figure 2A, 2B) and range in between $0.02 \mathrm{~mm}$ and $0.5 \mathrm{~mm}$ in size.
The proportion of monocrystalline grains is higher (74-84\%) than the polycrystalline quartz grains (15-17\%). The non-undulatory monocrystalline variety $(\mathrm{Qn})$ is more common than undulatory variety $(\mathrm{Qu})$. The plots on a $\mathrm{QtFL}$ diagram (figure 4A) show a higher percentage of quartz grains (Qt81F6L12) due to deficiency of feldspar. The dataset plot in the recycled orogen field of Dickinson (1985). The distribution as Qm78F6L14 is prominent (figure $5 \mathrm{~A}$ ), while the QpLvLsm plots diagram indicate a collisional suture and fold thrust belt as the provenance (figure 6A). Potash and plagioclase feldspars account for $3 \%$ of the bulk and shows lamellar twining (figure 2C). Feldspars show greater roundness index than quartz grain although partial dissolution and alteration is common in constituent feldspars. Lithic fragments are more rounded than quartz and feldspar grains. Sedimentary fragments are abundant (9.7-15.7 modal \%) and $60 \%$ of the total lithic fragments are represented by shale (these are mud clasts according to some workers), and siltstone (figure 2B) while the remaining fragments are chert. Cement comprises nearly $4.3 \%$ of the rock volume and is identified as rim cement of siliceous and ferruginous composition. In some thin sections, tiny grains of muscovite, zircon, tourmaline and epidote are recorded. Rare grains of euhedral zircon (figure 2G, H) and flakes of muscovite indicate a plutonic source rock with short transport to the depositional basin. Relative abundance of various detrital components suggests quartz rich recycled sedimentary source area for the LBS.

\subsection{Upper Bhander Sandstone Formation} (UBS)

\subsubsection{Modal analysis}

Quartz grains are subangular to subrounded, well sorted and show authigenic growth rims. Monocrystalline quartz $(\mathrm{Qm})$ is more abundant than the polycrystalline variety $(\mathrm{Qp})$ (figure $2 \mathrm{E}$ ) and the non-undulatory monocrystalline quartz (Qn) exceeds undulatory monocrystalline quartz $(\mathrm{Qu})$. The detrital grains invariably are coated with thin brown rim of iron oxide. The amount of quartz in UBS framework $(81+10 \%)$ is greater than those in LBS. The QtFL diagram (figure 4B) reflects high percentage of quartz grains (Qt90F2L8), while the QmFLt plot illustrates (figure 5B) the dominance of lithoclasts (some researchers interpret them as rip-up clasts) and relatively low amount of feldspar (Qm88F2L10). The UBS has less polycrystalline quartz compared to the population of sedimentary lithic fragments (Qp65Lv0Ls35). Concavo-convex grain contacts are observed in the thin section (figure 2D), caused by compaction 
Table 2. Modal analyses and recalculated data for selected sandstone samples, (LBS) for Lower formation while (UBS) for Upper formation.

\begin{tabular}{|c|c|c|c|c|c|c|c|c|c|c|c|}
\hline Sample no. & $\mathrm{Qt}$ & $\mathrm{F}$ & $\mathrm{L}$ & Total & $\mathrm{Qm}$ & $\mathrm{F}$ & $\mathrm{Lt}$ & Qp & $\mathrm{Lv}$ & Ls & $\mathrm{CT}$ \\
\hline LBS1 & 79 & 9 & 12 & 100 & 77.4 & 9 & 13.6 & 46.7 & 0 & 53.3 & 5.8 \\
\hline LBS2 & 81.8 & 6 & 12.2 & 100 & 79.3 & 6 & 14.7 & 56.3 & 0 & 43.7 & 4.8 \\
\hline LBS3 & 78.2 & 7 & 14.8 & 100 & 75.2 & 7 & 17.8 & 51.6 & 0 & 48.4 & 4.3 \\
\hline LBS4 & 79.5 & 5 & 15.5 & 100 & 75.6 & 5 & 19.4 & 55 & 0 & 45 & 5.5 \\
\hline LBS5 & 82 & 5 & 13 & 100 & 79 & 5 & 16 & 58 & 0 & 42 & 4.4 \\
\hline LBS6 & 82.3 & 4 & 13.7 & 100 & 79.3 & 4 & 16.7 & 55 & 0 & 45 & 3.7 \\
\hline LBS7 & 78 & 8 & 14 & 100 & 74.7 & 8 & 17.3 & 55.5 & 0 & 44.5 & 3.9 \\
\hline LBS8 & 78.3 & 9 & 12.7 & 100 & 75.5 & 9 & 15.5 & 55.7 & 0 & 44.3 & 3.5 \\
\hline LBS9 & 81 & 7 & 12 & 100 & 76.5 & 7 & 16.5 & 56.3 & 0 & 43.7 & 4.6 \\
\hline LBS10 & 83 & 6 & 11 & 100 & 81.7 & 6 & 12.3 & 53 & 0 & 47 & 4.2 \\
\hline LBS11 & 76.7 & 9 & 14.3 & 100 & 75.3 & 9 & 15.7 & 42.4 & 0 & 57.6 & 4.8 \\
\hline LBS12 & 80.5 & 8 & 11.5 & 100 & 78.7 & 8 & 13.3 & 58.5 & 0 & 41.5 & 5.1 \\
\hline LBS13 & 83.3 & 7 & 9.7 & 100 & 80.5 & 7 & 12.5 & 56 & 0 & 44 & 4.5 \\
\hline LBS14 & 85.2 & 4 & 10.8 & 100 & 82.5 & 4 & 13.5 & 64 & 0 & 36 & 4.7 \\
\hline LBS15 & 85.3 & 5 & 9.7 & 100 & 83 & 5 & 12 & 64 & 0 & 36 & 3 \\
\hline LBS16 & 84.6 & 4 & 11.4 & 100 & 80 & 6 & 14 & 59.1 & 0 & 40.9 & 3.7 \\
\hline LBS17 & 88.7 & 3 & 8.3 & 100 & 84.7 & 5 & 10.3 & 69.3 & 0 & 30.7 & 3.1 \\
\hline Average & 81.6 & 6.2 & 12.1 & 100 & 78.7 & 6.4 & 14.7 & 56.2 & 0 & 43.7 & 4.3 \\
\hline Std Dev. & 3.1 & 1.9 & 1.94 & & 3.05 & 1.69 & 2.38 & 6.25 & 0 & 6.25 & 0.78 \\
\hline UBS1 & 89 & 2 & 9 & 100 & 88.3 & 2 & 9.7 & 43 & 0 & 57 & 3 \\
\hline UBS2 & 85.9 & 3 & 11.1 & 100 & 85 & 3 & 12 & 41.5 & 0 & 58.5 & 3.8 \\
\hline UBS3 & 90 & 1 & 9 & 100 & 88.8 & 1 & 10.2 & 56.5 & 0 & 43.5 & 4.0 \\
\hline UBS4 & 92 & 1 & 7 & 100 & 91.3 & 1 & 7.7 & 53.3 & 0 & 46.7 & 3.9 \\
\hline UBS5 & 91.5 & 1 & 7.5 & 100 & 89.7 & 1 & 9.3 & 72.3 & 0 & 27.7 & 4.6 \\
\hline UBS6 & 92.5 & 1 & 6.5 & 100 & 90.5 & 1 & 8.5 & 76.7 & 0 & 23.3 & 4.3 \\
\hline UBS7 & 91 & 1 & 8 & 100 & 83 & 8 & 9 & 66.6 & 0 & 33.4 & 5.3 \\
\hline UBS8 & 89 & 3 & 8 & 100 & 88 & 3 & 9 & 55.5 & 0 & 44.5 & 5.6 \\
\hline UBS9 & 92.5 & 1 & 6.5 & 100 & 91.7 & 1 & 7.3 & 61.3 & 0 & 38.7 & 4.5 \\
\hline UBS10 & 88.7 & 2 & 9.3 & 100 & 87.5 & 2 & 10.5 & 53.3 & 0 & 46.7 & 4.5 \\
\hline UBS11 & 92.8 & 1 & 6.2 & 100 & 91.7 & 1 & 7.3 & 71.8 & 0 & 28.2 & 6.6 \\
\hline UBS12 & 93 & 1 & 6 & 100 & 89.7 & 1 & 9.3 & 67.6 & 0 & 32.4 & 3 \\
\hline UBS13 & 89.8 & 3 & 7.2 & 100 & 88 & 3 & 9 & 73.6 & 0 & 26.4 & 3.2 \\
\hline UBS14 & 90.2 & 2 & 7.8 & 100 & 88.3 & 2 & 9.7 & 70.8 & 0 & 29.2 & 4.2 \\
\hline UBS15 & 88.3 & 1 & 10.7 & 100 & 85 & 1 & 14 & 68.2 & 0 & 31.8 & 4.7 \\
\hline UBS16 & 93.3 & 1 & 5.7 & 100 & 91.3 & 1 & 7.7 & 81.4 & 0 & 18.6 & 4.9 \\
\hline UBS17 & 94 & 1 & 5 & 100 & 92.7 & 1 & 6.3 & 80 & 0 & 20 & 4.5 \\
\hline UBS18 & 87.2 & 4 & 8.8 & 100 & 85 & 4 & 11 & 68 & 0 & 32 & 4.8 \\
\hline UBS19 & 89.4 & 2 & 8.6 & 100 & 87 & 2 & 11 & 70.9 & 0 & 29.1 & 6.1 \\
\hline UBS20 & 88 & 3 & 9 & 100 & 84 & 3 & 13 & 64 & 0 & 36 & 6.3 \\
\hline Average & 90.4 & 1.75 & 7.8 & 100 & 88.3 & 2.1 & 9.58 & 64.8 & 0 & 35.1 & 4.6 \\
\hline Std Dev. & 2.24 & 0.96 & 1.62 & & 2.82 & 1.68 & 1.95 & 11.21 & 0 & 11.21 & 1.01 \\
\hline
\end{tabular}

Note: $\mathrm{Qt}=$ quartz total, $\mathrm{Qm}=$ quartz monocrystalline, $\mathrm{Qp}=$ quartz polycrystalline, $\mathrm{F}=$ feldspar, $\mathrm{L}=$ lithic fragments, $\mathrm{Lv}=$ lithic fragments (volcanic), $\mathrm{Ls}=$ lithic fragments (sedimentary), Lt = lithic fragments total (volcanic + sedimentary), $\mathrm{CT}=$ cement.

of quartz grain. Orthoclase is more abundant than microcline but constitutes a small proportion $(1-3 \%)$ of the rock. These grains are well rounded and show clay and iron oxide coatings. Plagioclase is rather rare. Lithic fragments include siltstone, shale, sandstone and chert in decreasing order of abundance. Volcanic fragments are subordinate (Qp65Lv0Ls35). Cement (3-6\%) occur as dust rims (figure $2 \mathrm{~F}$ ) and are mainly Fe-oxides and partly siliceous. Secondary iron oxides, detrital biotite, zircon and tourmaline are accessory minerals. 

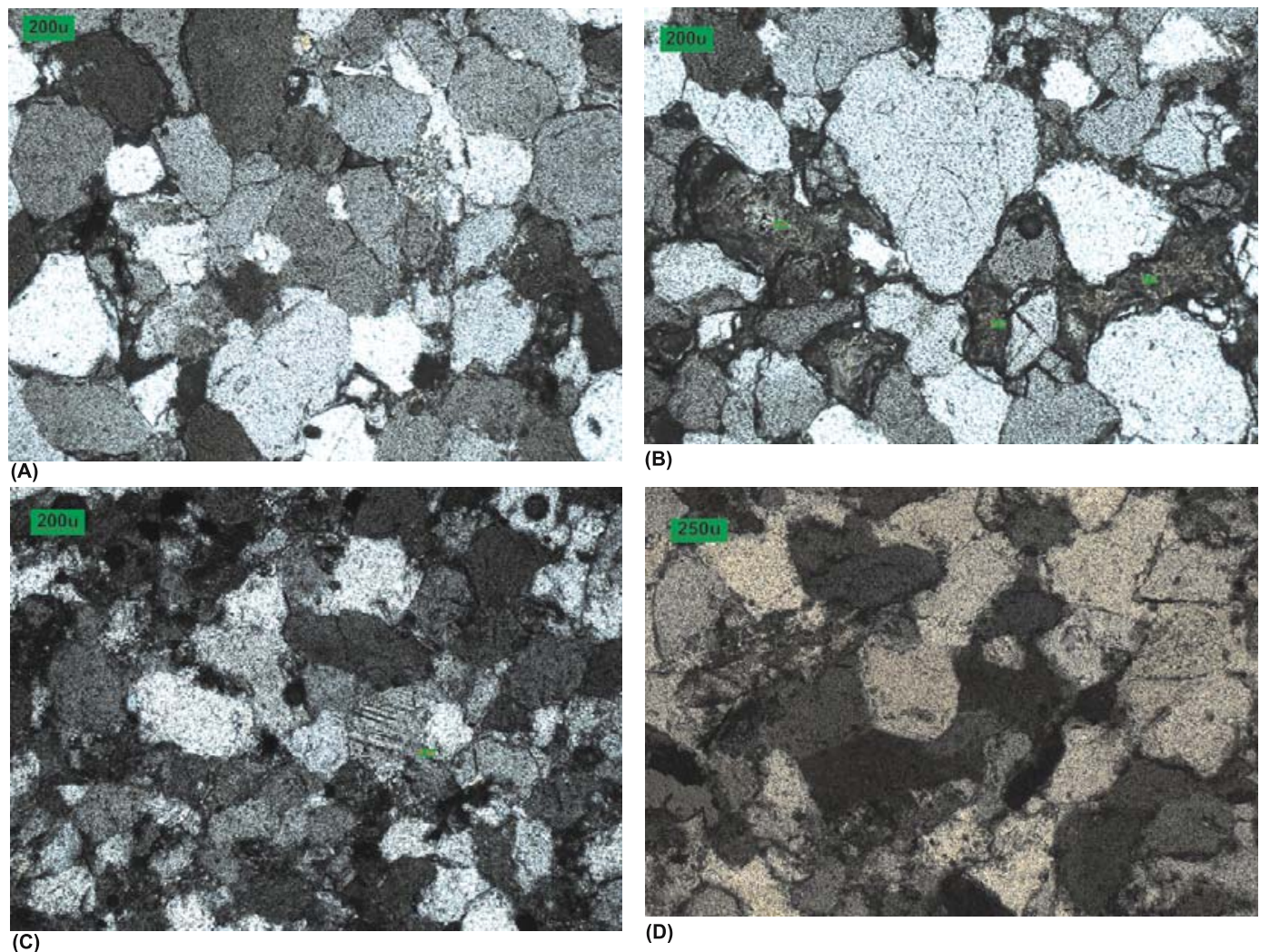

(C)

(D)
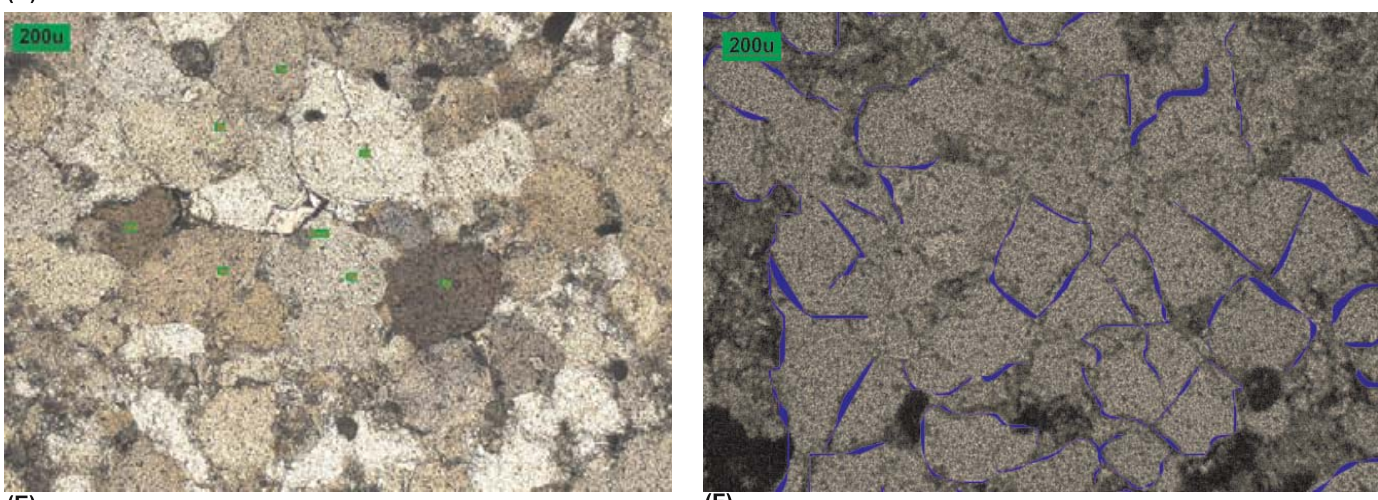

(E)

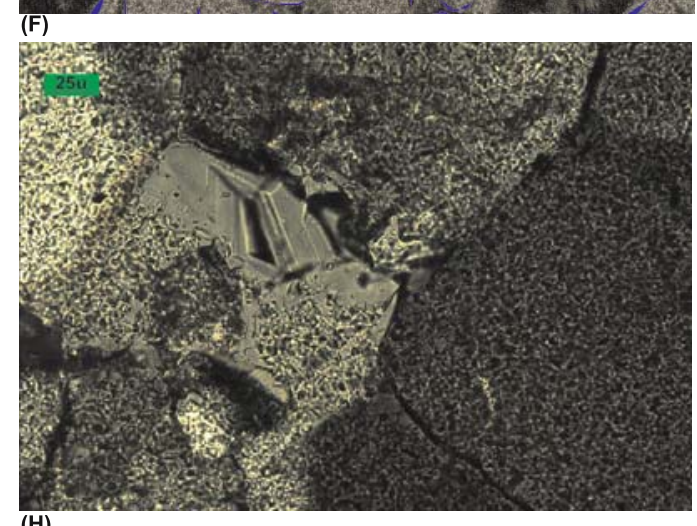

(G)

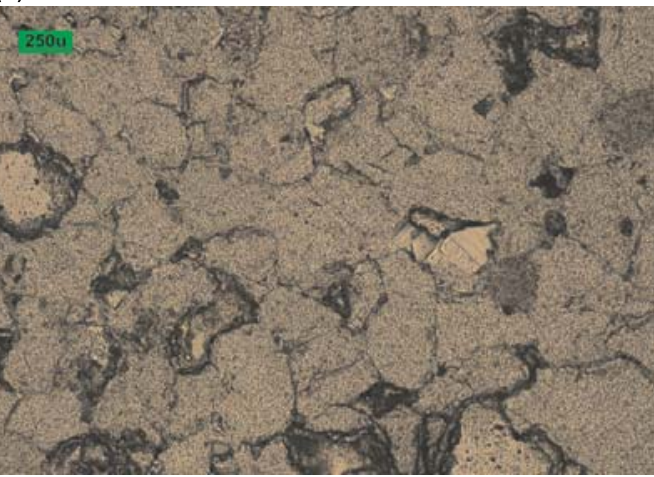

(H)

Figure 2. (A, B) Photomicrographs of LBS showing overgrowth of monocrystalline quartz with polycrystalline quartz grain. Grains are compacted with concavo-convex sutured boundaries. Recrystalline feature like triple junctions are common in the polycrystalline quartz grain. Lithic fragments consist mainly of reworked sedimentary grain. Bar scale $200 \mu \mathrm{m}$.

(C) Detrital grain of plagioclase feldspar exhibiting lamellar twin. Bar scale $200 \mu \mathrm{m}$. (D, E) Photomicrographs of UBS showing population of undulated quartz grain of metamorphic source. Bar scale 200 to $250 \mu \mathrm{m}$. (F) Digital image analysis of cement occupied area in thin section. Cements are mainly ferruginous to silica in composition. Bar scale $200 \mu \mathrm{m}$. (G, H) Pristine detrital zircon exhibits different zoning and at the centre development of rectangle rims is prominent. Bar scale 25 to $250 \mu \mathrm{m}$. 


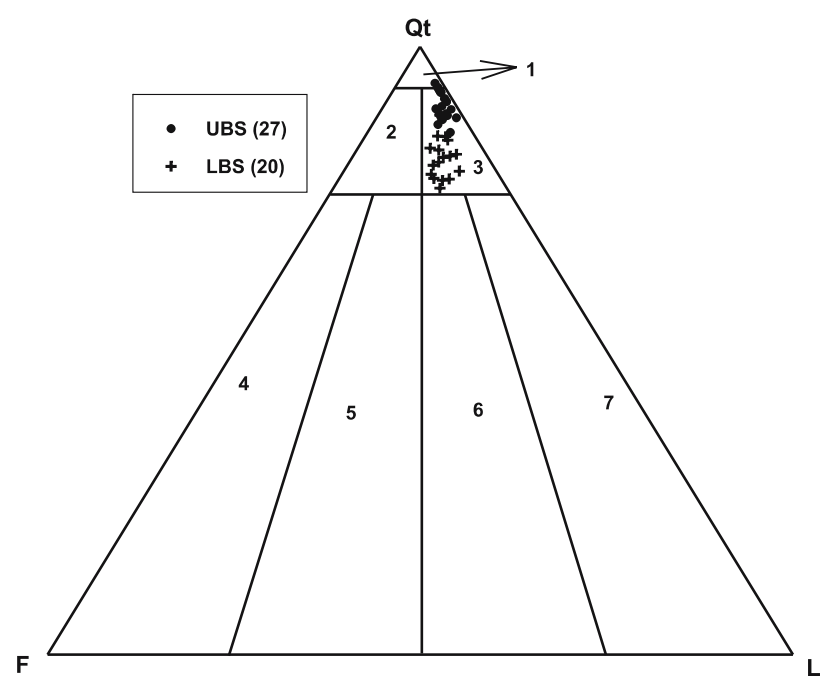

Figure 3. QtFL plot (after Folk 1968) for the Lower and Upper Bhander sandstones. Key to the field: 1. Quartz arenite; 2. Subarkose; 3. Sublitharenite; 4. Arkose; 5. Lithic arkose; 6. Feldspathic litharenite; 7. Litharenite.

\section{Geochemical characteristics}

\subsection{Major element}

Geochemistry of sedimentary rocks has been related to plate tectonic setting (Bhatia 1983; Roser and Korsch 1986, 1988; Naqvi et al 1988; McLennan et al 1990; Banerjee and Bhattacharya 1994) and therefore provides insights to the tectonic evolution of the terrain. Major element chemistry gives clue to the provenance type as well as weathering conditions which in turn controlled by the tectonic setting of the basin. Major element oxide composition of the Bhander sandstone is given in table 3 . The average $\mathrm{SiO}_{2}$ content for UBS $(78.05 \%)$ and for LBS $(70.16 \%)$ reflects high quartz content of these supermature sandstones. $\mathrm{SiO}_{2}$ increases with $\mathrm{Al}_{2} \mathrm{O}_{3}, \mathrm{TiO}_{2}$ and $\mathrm{K}_{2} \mathrm{O}$ whereas $\mathrm{MgO}, \mathrm{CaO}$ and $\mathrm{Na}_{2} \mathrm{O}$ decreases in both the sandstone units. The absolute amount of quartz and the chemically unstable grains determine the extent and range of chemical variations. Small amount of $\mathrm{CaO}$ and $\mathrm{Na}_{2} \mathrm{O}$ contents are clearly contributed by the plagioclases, and such low concentrations corroborate the petrographic observation. Moderate values of $\mathrm{K}_{2} \mathrm{O}$ reflect derivation from $\mathrm{K}$-feldspars and micas. $\mathrm{TiO}_{2}$ values in the LBS suggest derivation from the $\mathrm{TiO}_{2}$ containing opaque minerals. High $\mathrm{Al}_{2} \mathrm{O}_{3}$ is due to the presence of clays and subordinate micas. The UBS contain substantial $\mathrm{Fe}_{2} \mathrm{O}_{3}$ derived from the iron oxide in the grain boundary cement, while $\mathrm{MnO}$ and $\mathrm{P}_{2} \mathrm{O}_{5}$ do not show any significant variation pattern. Very low $\mathrm{MnO}$ content in all sandstone samples reflect low $\mathrm{Eu}$ of the depositional basin.

\subsection{Trace element}

Most of the trace elements given in table 4, like $\mathrm{Sr}$ and ferromagnesian elements ( $\mathrm{Ti}, \mathrm{Sc}$, and $\mathrm{V}$ ) show negative correlation with $\mathrm{Si}$, whereas large cation elements ( $\mathrm{Rb}$ and $\mathrm{Pb})$, highly charged cation elements (La and Nd) and HFSE elements like Zr and Hf show increasing trend with silica. This indicates that clastic detritus was associated with quartzose source component. Sr is depleted due to the recycling of feldspar with increasing maturity.

\subsubsection{Ferromagnesian trace elements}

In most mafic igneous rocks $\mathrm{Cr}, \mathrm{Co}, \mathrm{Ni}, \mathrm{T}$ and $\mathrm{V}$ show similar chemical behaviour, which on a weathering regime gets fractionated. In LBS sample, Cr content $97-111 \mathrm{ppm}$ is lower than the concentration in the UBS samples (103-227 ppm) suggesting slight enrichment with respect to chromium during the weathering of the Upper Sandstone. A moderately positive correlation of Cr with Ni (figure 7E) in the UBS suggests local control of the source rocks, whereby basic rocks provided additional inputs during the sedimentation of the UBS. High Th/Sc ratios (figure 7C) in both sandstone formations point to substantial input from highly differentiated rocks such as granites $(\mathrm{Th} / \mathrm{Sc}=4.06)$. Similar observations were also made by Paikaray et al (2008).

\subsubsection{LILE and HFSE trace elements}

Some LILE and HFSE elemental ratios like $\mathrm{Rb} / \mathrm{Sr}$, $\mathrm{Zr} / \mathrm{Hf}$ given in table 4, are often used for tectonic setting interpretations. Similarly, LBS with $3867 \mathrm{ppm}$ of $\mathrm{Zr}$ and UBS with $600 \mathrm{ppm}$ reflects granite rich source rock. HFSE elements like Zr, $\mathrm{Nb}$ and Ta belong to an important group of element which provides monitoring the provenance. The average $\mathrm{Th} / \mathrm{U}$ ratio in the Bhander sandstones (4.4 ppm) is similar to that of PAAS (4.7), whereas $\mathrm{La} / \mathrm{Th}$ ratios vary between 1.6 and 2.2 which is lower than the PAAS (2.6). Elements like $\mathrm{Zr}, \mathrm{Nb}, \mathrm{Hf}$, Th and $\mathrm{U}$ are partitioned in the igneous melt during crystallization and as a result these elements are found in abundance in the felsic rocks. Th and $U$ are highly incompatible elements and remain unfractionated during the diagenesis and therefore used for the discrimination of provenance types. A unique correlation of $\mathrm{Zr}$ to Hf (figure 7F) points to high Hf content of the associated zircon. A moderately positive correlation of $\mathrm{Yb}$ and $\mathrm{Zr}$ (figure $7 \mathrm{~J}$ ) in both sandstone formations suggests that heavy REE in these rocks are governed by the zircon population (table 4). Being resistant to weathering and alteration these elements impart a 

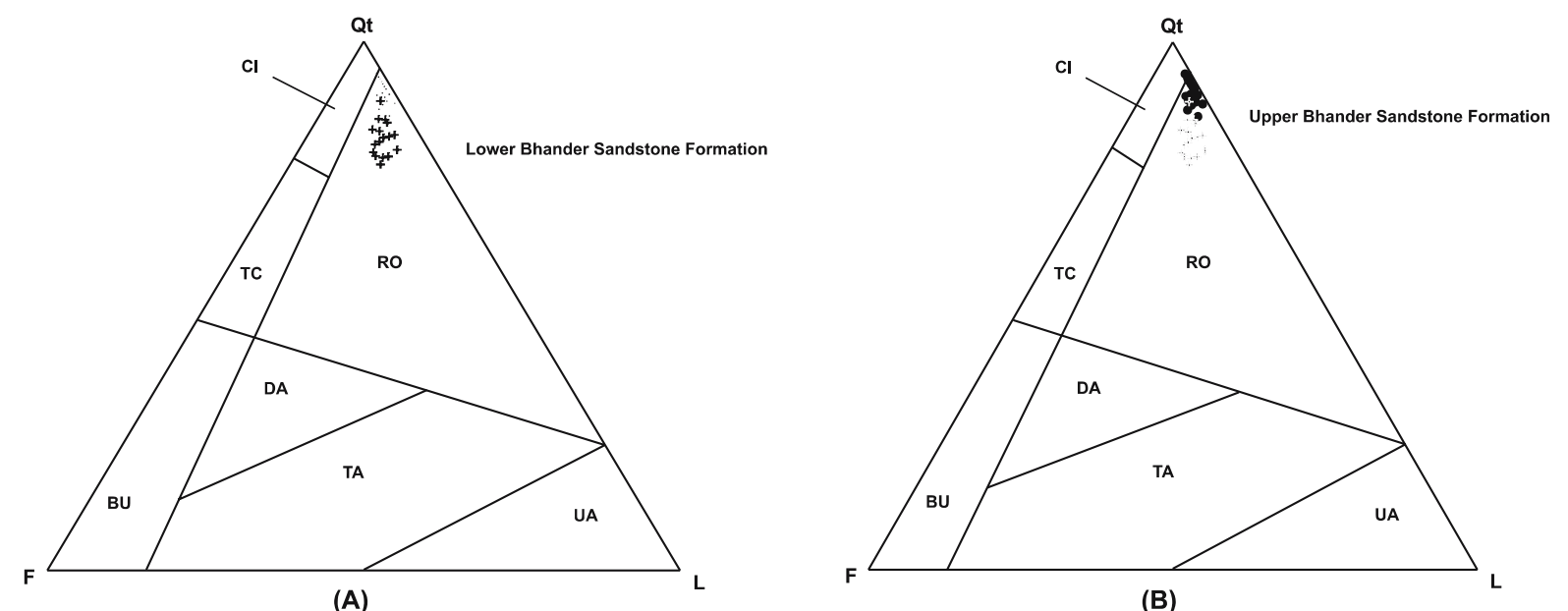

Figure 4(A and B). Ternary QtFL plots of the framework mode of the Lower and Upper Bhander sandstones, showing different provenance fields proposed by Dickinson (1985). Key to the provenance field: BU - basement uplift; TC - transitional continental; CI - craton interior; RO - recycled orogen; DA - dissected arc; TA - transitional arc; UA - undissected arc.

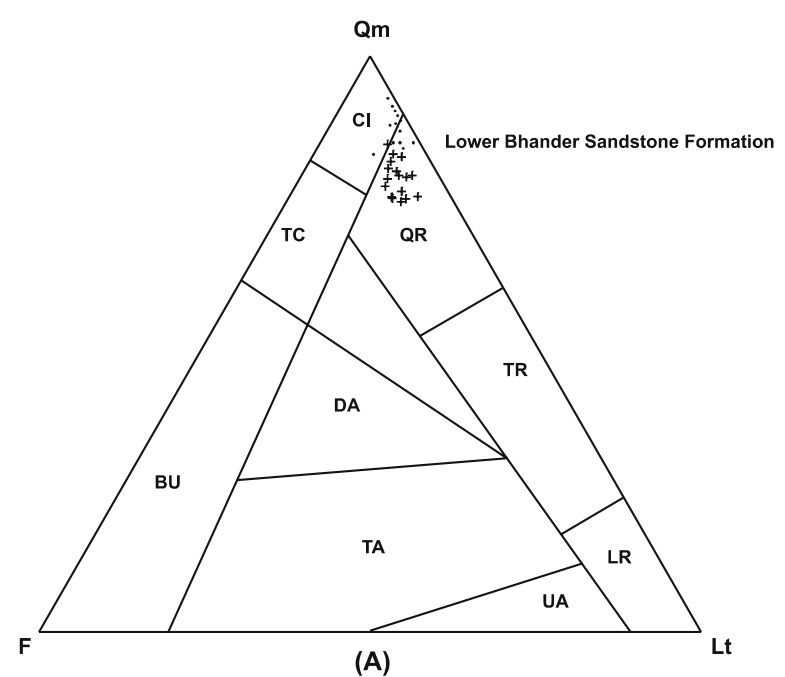

(A)

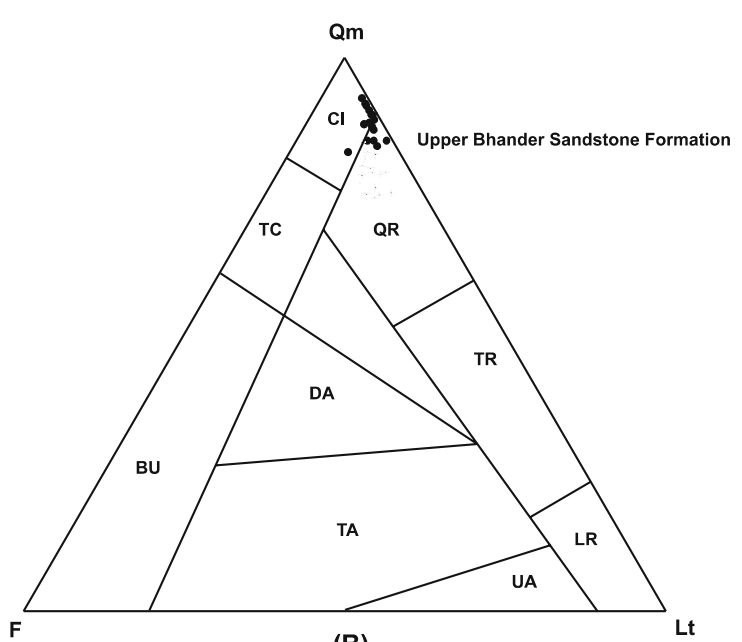

(B)

Figure 5(A and B). QmFLt plots for framework modes of the Lower and Upper Bhander sandstones showing different provenance fields by Dickinson and Suczek (1979); Dickinson et al (1983). Key to provenance field: BU - basement uplift; TC - transitional continental; CI - craton interior; QR - quartzose recycled; TA - transitional recycled; LR - lithic recycled; DA - dissected arc; TA - transitional arc; UA - undissected arc.

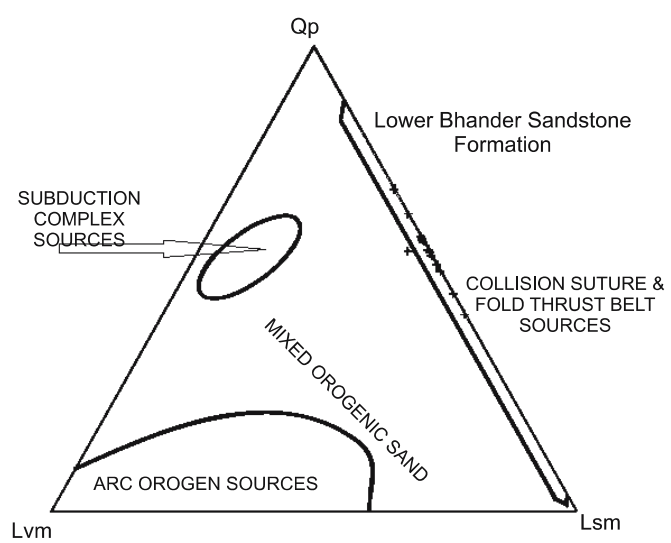

(A)

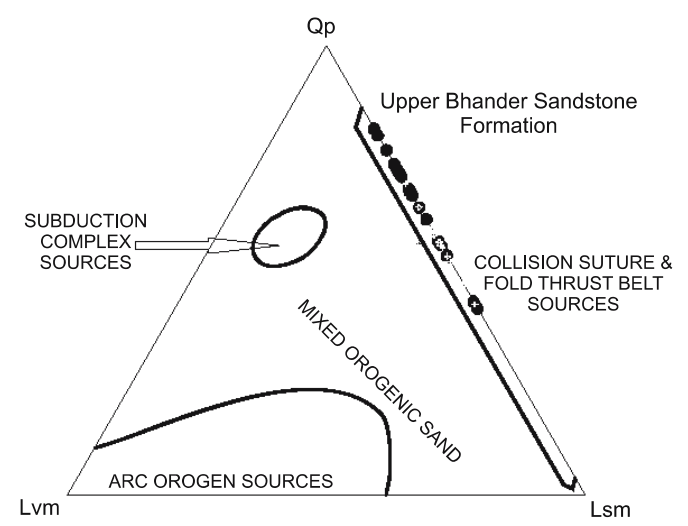

(B)

Figure 6(A and B). QpLvLs plots for framework modes of the Lower and Upper Bhander sandstone formations showing different provenance fields by Dickinson and Suczek (1979). 
distinct chemistry to the rock. Some significant differences in the elemental ratios in two sandstone populations suggest local control of sediment composition. The $\mathrm{Cr} / \mathrm{Th}$ ratio in the rocks of UBS is significantly higher $(13-38)$ while $\mathrm{La} / \mathrm{Sc}$ ratio is significantly lower (5-7) than that of LBS. In contrast, the average $\mathrm{Cr} / \mathrm{Th}$ ratio (3) is significantly lower and the La/Sc ratio (8-9) is significantly higher in the LBS formation suggesting more silicic source for the latter, than in the former. The plots between $\mathrm{Th} / \mathrm{U}, \mathrm{Th} / \mathrm{Sc}, \mathrm{Cr} / \mathrm{Ni}, \mathrm{Zr} / \mathrm{Hf}, \mathrm{La} / \mathrm{Zr}$, $\mathrm{La} / \mathrm{Sc}, \mathrm{La} / \mathrm{Yb}$ and $\mathrm{Yb} / \mathrm{Zr}$ (figure 7B, C, E, F, G, H, $\mathrm{I}, \mathrm{J})$ indicate distinct division between two groups of sample population.

\subsection{Rare earth elements}

The REE abundance and the distribution pattern of the analytical data are useful in understanding the petrogenesis of different types of arenites (Bhatia 1985; Bhatia and Crook 1986; McLennan 1989; Condie 1991; McLennan and Taylor 1991). REEs are among the most important group of elements in terms of provenance indicator. Total rare earth elemental concentration of UBS is (mean $76 \mathrm{ppm})$ is lower than PAAS (183 ppm) whereas LBS (mean $275 \mathrm{ppm}$ ) is greater than PAAS (table 5). The chondrite normalized REE distribution in LBS and UBS show LREE enrichment, significant negative Eu anomaly and a flat smooth distribution pattern for the HREE (figure 8). The LREE enrichment (2.6 to $4.17 \mathrm{La} / \mathrm{Sm}$ ) is reflected in the analytical data and near constant value of HREE Gd/Yb ranges between $\sim 0.8$ and -1.2 . REE is generally not lost during weathering; hence the Eu anomaly seen in the sandstone samples may not be attributed to effects of weathering. The negative $\mathrm{Eu}$ anomalies are therefore attributed to the presence of Eu depleted felsic rocks, such as granite in the source region (Gao and Wedepohl 1995). The arenites of the LBS show very strong negative $\mathrm{Eu}$ anomaly (figure 8) similar to those of PAAS (Taylor and McLennan 1985). High enrichment of LREE in LBS is controlled mainly by the abundance of heavy minerals like zircon which is corroborated by the presence of high amount of $\mathrm{Zr}$ element (mean $3875 \mathrm{ppm}$; see table 5) and partly by the micaceous minerals (muscovite and biotite), whereas in UBS samples LREE are controlled in part by the micaceous minerals and partly by the clay minerals. The chondrite normalized REE patterns of the Bhander sandstones are characterized by the presence of pronounced negative $\mathrm{Eu}$ anomaly and high $\mathrm{La} / \mathrm{Yb}$ ratio (6.5 to 7.8 , figure $7 \mathrm{I}$ ). These values resemble the craton derived rocks (Bhatia 1985). The modal percentage of detrital zircons in thin sections (1-3.5\%) of both the sandstone types validates this observation. 


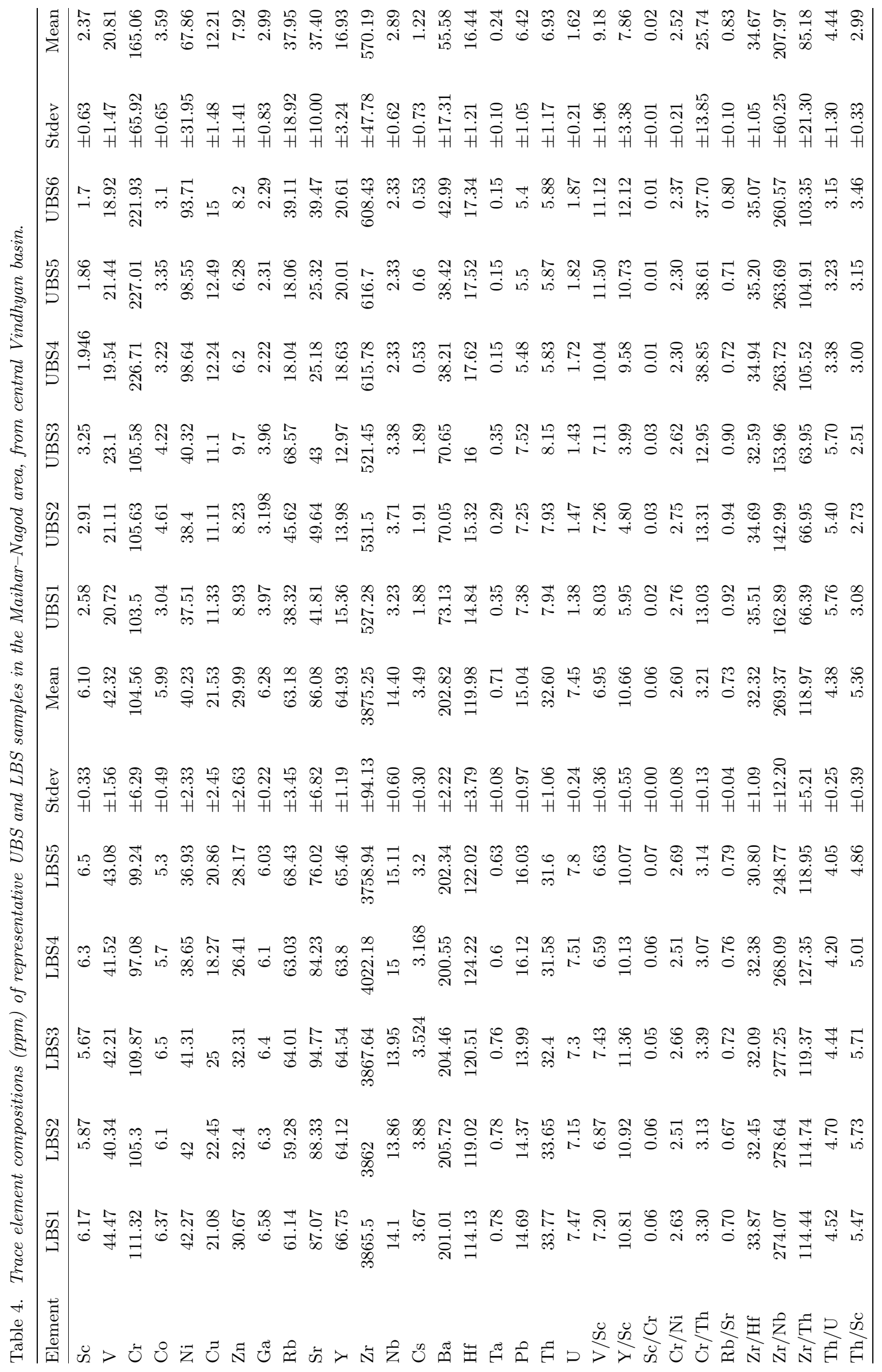



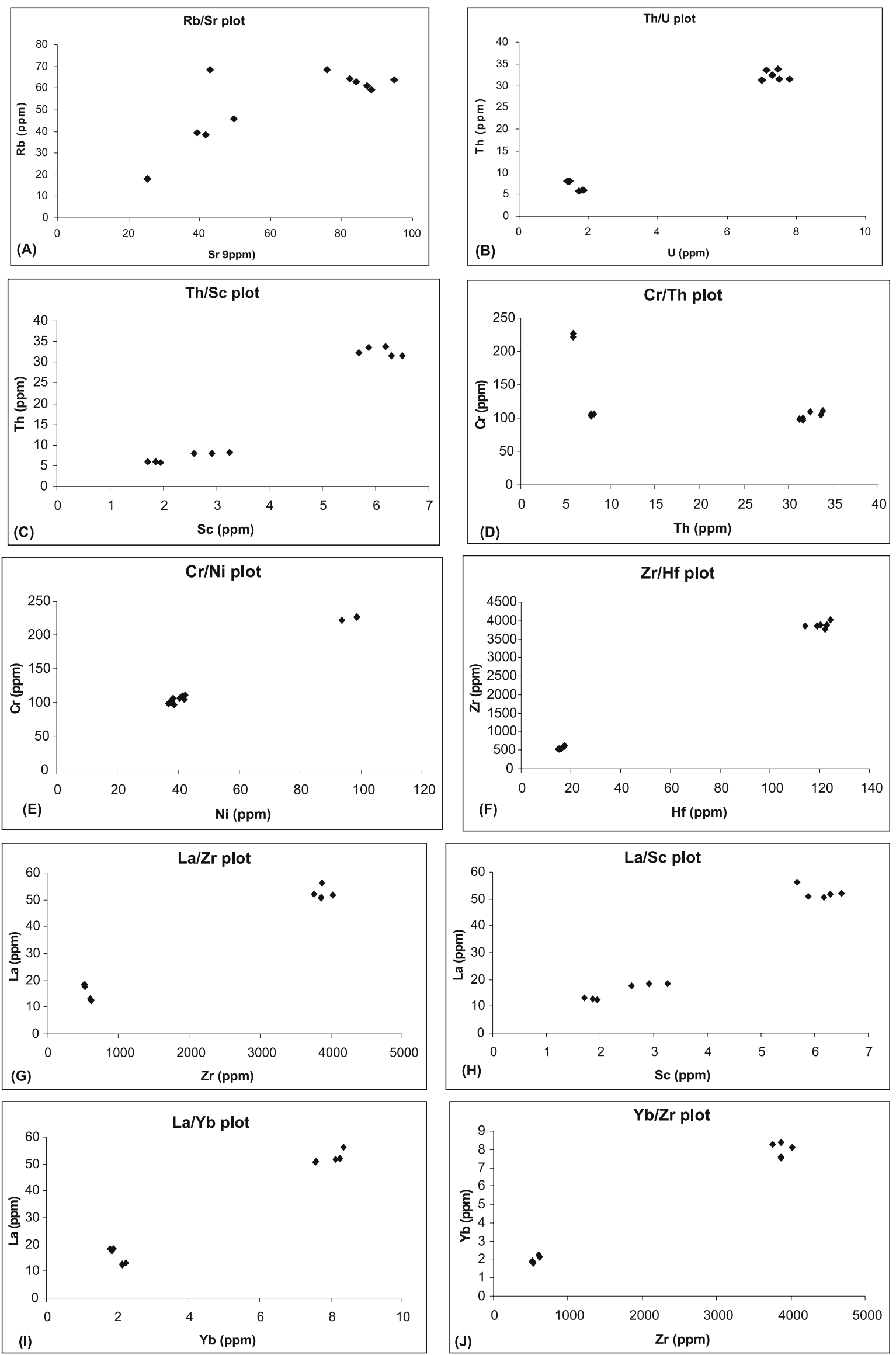

Figure 7. (A-J) show various bilinear plots of trace element ratios of sandstone samples of the Bhander Group. 


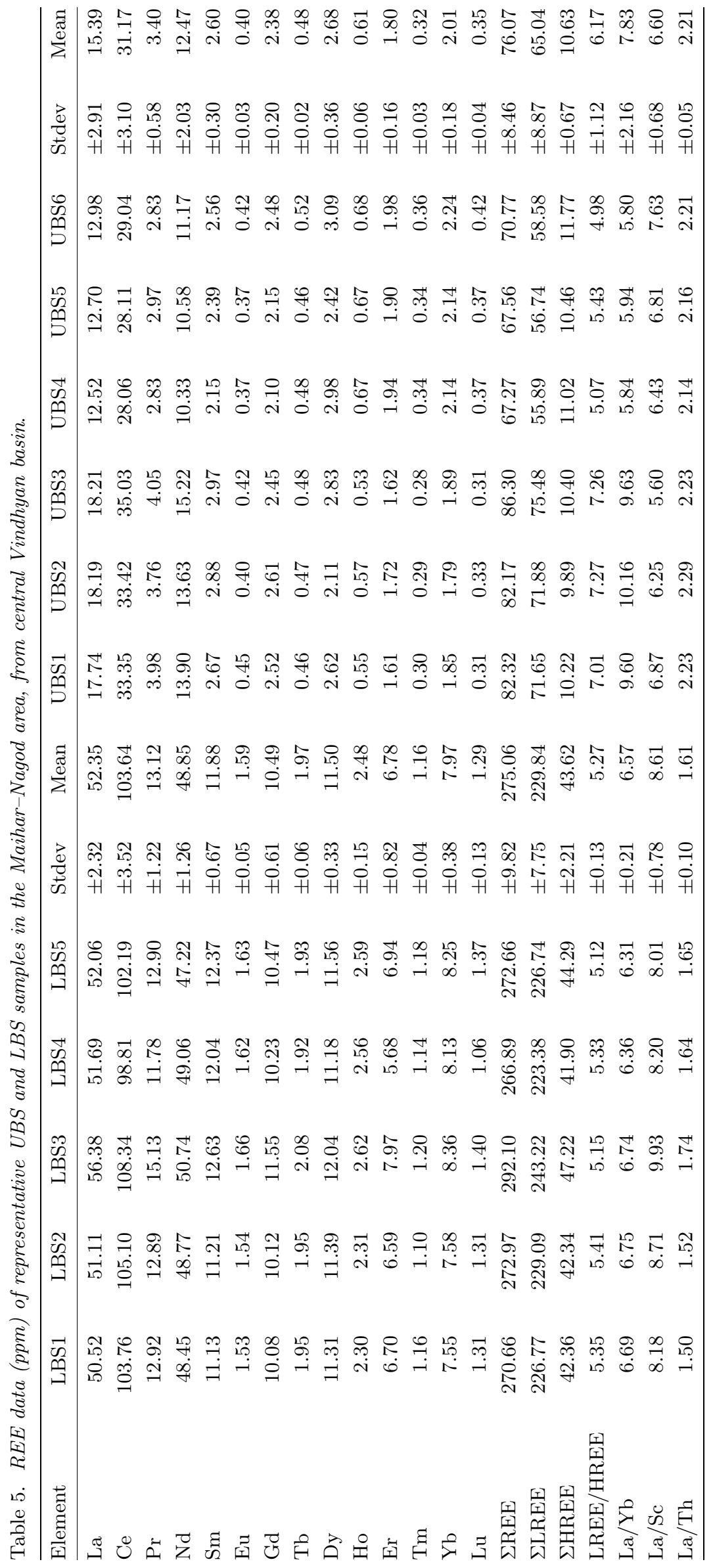




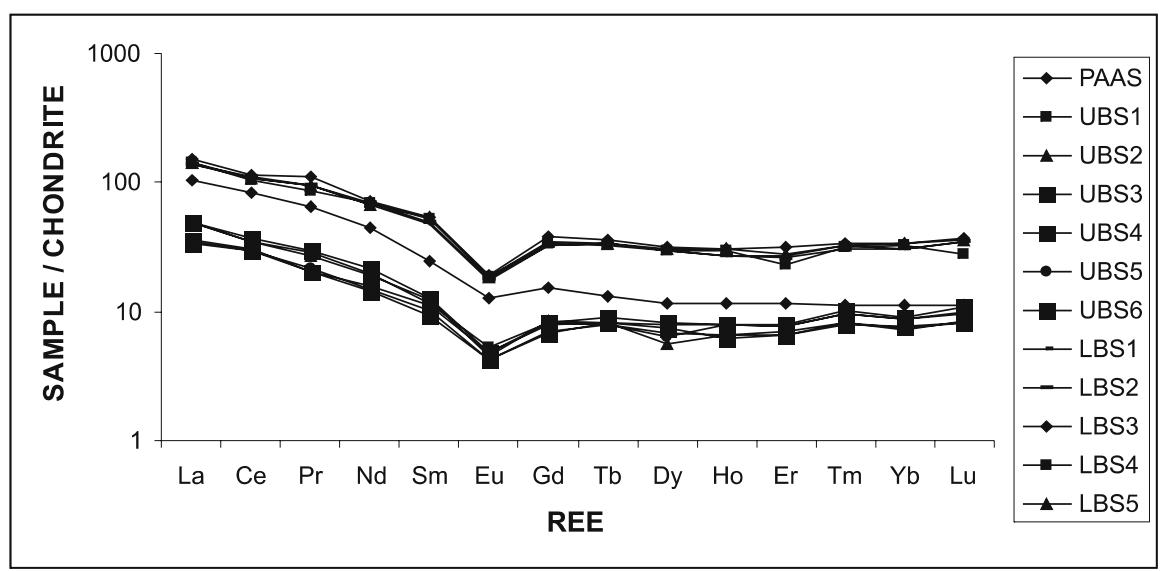

Figure 8. Chondrite-normalized (sample/chondrite) (REE) distribution pattern of the sandstone samples of the Bhander Group in the central Vindhyan basin.

\section{Interpretation}

\subsection{Petrographic modal interpretation}

A series of ternary diagrams are used to plot the sandstone detrital mode data for the LBS and UBS using (Dickinson 1985) plots QtFL. Both LBS and UBS can be inferred to have received its sand grains from a mixed provenance, represented by the craton interior to recycled orogen. Similarly, the QmFLt ternary plots for the same set of samples suggest derivation from the craton interior to quartzose recycled terrain. Greater abundance of monocrystalline quartz over polycrystalline quartz reflects an increase in the maturity index. Lower abundance of feldspar as well as volcanic fragment also supports the dominance of a recycled sedimentary source. Feldspar depletion is apparently caused by intense recycling. The QpLvLs plots (figure 6A, B) for both the formations point towards minor contribution of the collision suture and fold thrust belt. Muscovite in LBS is suggestive of recycled orogenic provenance where as biotite in UBS seems to reflect aridity in the source region. Relatively more aridity in the depositional site is indicated by the ubiquitous iron oxide cement $(3-6 \%)$.

Modal analysis given in previous pages indicates $60 \%$ of the total lithic fragments are siltstone. Shale and sub-rounded abraded chert constitutes the rest. The rounded lithic fragments are obviously derived from the recycled sedimentary sources. Compaction by cement formation is evident from interpenetrative grain contacts mostly concavo-convex and sutured (figure 2B). These features indicate progressive nature of the compaction process, which seem to have started at the sediment-water interface and continued till the burial. Angularity of zircon grains indicate short transport of the sand constituents which appear to be derived from a granitic source. It is apparent that sandstone samples plotting into the recycled orogen field of the Dickinson diagrams (figures 4,5) are typical of an intracratonic basin deposit where immature sediments are derived from the adjacent tectonically active highlands.

\subsection{Geochemical interpretation}

Geochemical interpretation of the sandstone analysis is adequately supported by the petrographic data generated from the detrital constituents. The sandstones of the Bhander Group by and large contain a fairly high amount of $\mathrm{SiO}_{2}(70-78 \%)$, and $\mathrm{Al}_{2} \mathrm{O}_{3}(7.53-11.42 \%)$. Presence of significant amount of HFSE such as Zr (570-3875 ppm), Hf

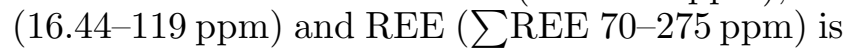
noteworthy. The source rocks seem to have high concentration of immobile elements like Th and $\mathrm{La}$ and low abundance of elements like Sc, Co and Cr. Ferromagnesian elements (Fe, Ti, Mg, Sc and $\mathrm{V}$ ) and small cation elements ( $\mathrm{Na}, \mathrm{Ca}$ and $\mathrm{Sr}$ ) show negative correlation with $\mathrm{SiO}_{2}$, whereas large cations $(\mathrm{K}, \mathrm{Rb}$ and $\mathrm{Pb})$ and highly charged cations ( $\mathrm{La}$ and $\mathrm{Nd}$ ) and high field strength elements like Zr and Hf show positive correlation with silica. This indicates that detritus was derived from quartz rich source and strongly influenced by the silicic nature of source rocks. It is evident from the petrography and geochemistry of the LBS and UBS formations, that two compositional groups can be identified. The geochemical gap shown by trace and rare earth elements suggests a variety of provenance types for the two formations of the Bhander Group. This compositional characteristic of different lithological units of the Bhander Group is closely influenced by the tectonics in the depositional basin. 


\section{Conclusion}

A critical evaluation of contrasting view points and detailed field study of the Bhander Group of sediments has prompted an invocation of a hypothesis that the Bhander sandstones from the central part of the Vindhyan basin are quartz rich arenite to sublitharenite and inferred to have been derived from the interior craton and some sort of recycled orogen. As demonstrated in the previous pages, the detrital mode and the element distribution pattern point to a dual source for sediment particles. On one hand, the continental interior with granitic/gneissic rocks of the Mahakoshal Group acted as a prominent source terrain, the other source terrain appear to be the recycled sedimentary prism of the exhumed sandstones of the Rewa and Kaimur Groups.

High $\mathrm{SiO}_{2}$ content of Lower Bhander Sandstone in the range of $70-85 \%$ reflect derivation from a stable craton where granitic source rocks are evident, characterized by high $\mathrm{Zr}$ content (600-3867 ppm) and characteristic $\mathrm{Zr} / \mathrm{Nb}$ and $\mathrm{Z} / \mathrm{Th}$ ratios. The samples of LBS with $\mathrm{Cr} / \mathrm{Th}$ ratio of $\sim 3: 1$ suggest derivation from a silica rich terrain of granites and other related silicate rocks. The negative Eu anomalies in these rocks are also attributed to the presence of Eu depleted felsic rocks such as granites in the source region. The interelemental bilinear plots for trace elements (figure 7A-J) show three types of population.

- disseminated scattered type,

- linear with positive correlation, and

- two population clusters. The third type of trace element clustering signifies the overall discriminating character between LBS and UBS. Such distribution patterns further corroborate the fact that the LBS sediments were derived from granite rich cratonic terrain whereas UBS was derived from mixed terrain and from time to time received detrital supplies from local sources due to recycling.

The QpLvLsm discrimination diagrams (figure 6A, B) after Dickinson and Suczek (1979) for the mineral constituents of the Bhander arenites indicate that the source area rocks to be the fold thrust belt, the evidence for which are found in the Mahakoshal Group of metamorphics in the Son Valley. Some geophysical studies (Mishra et al 2002) across the Satpura Mountain belt suggest that the Satpura fold belt represents a Proterozoic collision zone between the Bundelkhand Craton in the north and the Bhandara Craton in the south. If such a tectonic scenario was a reality, the sandstones of the Bhander Group could have formed as a foreland intracratonic sedimentary succession deriving its detritus from the Satpura fold belt.

\section{Acknowledgements}

We are indebted to Dr V Balaram for using XRF and ICP-MS facilities of the National Geophysical Research Institute, Hyderabad. Financial support of the Council of Scientific and Industrial Research, New Delhi, in the form of Senior Research Fellowship to the first author is thankfully acknowledged.

\section{References}

Auden J B 1933 Vindhyan sedimentation in the Son Valley, Mirzapur District; Geol. Surv. India Memoir 62 141-250.

Balaram V, Rao T Ganeshwara and Anjaiah K V 1999 International proficiency tests for analytical geochemistry laboratories: An assessment of accuracy and precision in routine geochemical analysis; J. Geol. Soc. India $\mathbf{5 3}$ 417-423.

Banerjee D M and Bhattacharya P 1994 Petrology and geochemistry of greywackes from the Aravalli Supergroup, Rajasthan, India and the tectonic evolution of a Proterozoic sedimentary basin; Precamb. Res. 67 11-35.

Basu A, Patranabis-Deb S, Chieber J and Dhang P C 2008 Stratigraphic position of the $\sim 1000 \mathrm{Ma}$ Sukhda tuff (Chattisgarh Supergroup, India) and $500 \mathrm{Ma}$ question; Precamb. Res. 167 383-388.

Basumallick S 1962 Certain sedimentological features of the Bhander Sandstone in Maihar, M.P.; Quart. J. Geol. Min. Soc. India 34 175-181.

Bhattacharyya A 1993 The Upper Vindhyans of Maihar Field Guide Book; Geol. Soc. India, Bangalore, pp 39-89.

Bhattacharya A, Sarkar S and Chanda S K 1980 Storm deposits in the Late Proterozoic Lower Bhander Sandstone of the Vindhyan Supergroup around Maihar, Satna District, Madhya Pradesh, India; J. Sedim. Petrol. 50 1327-1336.

Bhatia M R 1983 Plate tectonics and geochemical composition of sandstones; J. Geol. 91 611-627.

Bhatia M R 1985 Rare earth element geochemistry of Australian Palaeozoic graywackes and mudrocks: Provenance and tectonic control; Sed. Geol. 45 97-113.

Bhatia M R and Crook K A W 1986 Trace element characteristics of graywackes and tectonic setting discrimination of sedimentary basins; Contrib. Mineral. Petrol. 92 181-193.

Bose P K and Chaudhuri A K 1990 Tide versus storm in Epeiric coastal deposition: Two Proterozoic sequences, India; Geol. J. 25 81-101.

Bose P K, Sarkar S, Chakraborty and Banerjee S 2001 Overview of the meso- to neoproterozoic evolution of the Vindhyan basin, central India; Sed. Geol. 141-142 395-419.

Bose P K, Chakrabarty S and Sarkar S 1999 Recognition of ancient eolian dunes: A case study in Upper Bhander Sandstone, Son Valley, India; J. Sed. Res. 69(1) 74-81.

Chakrabarti A 1990 Trace and dubiotraces: Examples from the so called Late Proterozoic siliciclastic rocks of the Vindhyan Supergroup around Maihar, India; Precamb. Res. 47 141-153.

Chakrabarty R, Basu A R and Chakrabarty A 2007 Trace element and Nd-isotopic evidence for sediment sources in the mid-Proterozoic Vindhyan Basin, central India; Precamb. Res. 159 260-274.

Chanda S K and Bhattacharya A 1974 Ripple-drift cross lamination in tidal deposit: Examples from Precambrian Bhander Formation of Maihar, Satna district, Madhya Pradesh, India; Bull. Geol. Soc. Am. 85 1117-1122. 
Condie K C 1991 Another look at rare earth elements in shales; Geochim. Cosmochim. Acta 55 2527-2531.

Condie K C 1993 Chemical composition and evolution of the upper continental crust: Contrasting results from surface samples and shales; Chem. Geol. 104 1-37.

Condie K C, Wilkes M, Rosen D M and Zlobin V L 1991 Geochemistry of metasediments from the Hapschan Series, eastern Anabar Shield, Siberia; Precamb. Res. 50 $37-47$.

Crawford and Compston W 1970 The age of the Vindhyan system of Peninsular India; Quart. J. Geol. Soc. London 125 351-371.

Cullers R L 1994 The controls on the major and trace element variation of shales, siltstones and sandstones of Pennsylvanian-Permian age from uplifted blocks in Colorado to platform sediment in Kansas, USA; Geochim. Cosmochim. Acta 22 4955-4972.

Dickinson W R 1982 Compositions of sandstones in CircumPacific subduction complexes and fore-arc basins; $\mathrm{Am}$. Assoc. Petrol. Geol. Bull. 66 121-137.

Dickinson W R 1985 Interpreting provenance relations from detrital modes of sandstones; In: Provenance of Arenites (ed.) Zuffa G G (New York: D. Reidel Publ. Co.), pp. 333-361.

Dickinson W R 1988 Provenance and sediment dispersal in relation to paleotectonics and paleogeography of sedimentary basins; In: New Perspectives in Basin Analysis (eds) Kleinspehn K L and Paola C (Berlin: Springer-Verlag), pp. $3-25$.

Dickinson W R, Beard L S, Brakenridge G R, Erjavee J R, Ferguson R C and Inman K F 1983 Provenance of North American Phanerozoic sandstones in relation to plate tectonic setting; Geol. Soc. Amer. Bull. 94 222-235.

Dickinson W R and Suczek C A 1979 Plate tectonics and sandstone compositions; Am. Assoc. Pet. Geol. Bull. 63 $2164-2182$.

Folk R L 1968 Petrology of sedimentary rocks; Hemphills, Austin, Texas, 170 pp.

Gao S and Wedepohl K H 1995 The negative Eu anomaly in Archean sedimentary rocks: Implications for deposition, age and importance of their granitic sources; Earth Planet. Sci. Lett. 133 81-94.

Ingersoll R V, Bullard T F, Ford R L, Grimm J P, Pickle J D and Sares S W 1984 The effect of grain size on detrital modes: A test of the Gazzi-Dickinson point counting method; J. Sedim. Petrol. 54 103-106.

Kumar S 1976 Stromatolites from the Vindhyan rocks of Son Valley, Maihar area, District Mirzapur (U.P.) and Satna (M.P.); J. Pal. Soc. India 18 13-21.

Malone S J, Meert J G, Banerjee D M, Pandit M K, Tamrat E, Kamenov G D, Pradhan V R and Sohl L E 2008 Paleomagnetism and Detrital Zircon Geochronology of the Upper Vindhyan Sequence, Son Valley and Rajasthan, India: A ca. $1000 \mathrm{Ma}$ Closure age to the Purana Basins?; Precamb. Res. 164 137-159.

McLennan S M 1989 Rare earth elements in sedimentary rocks: Influence of provenance and sedimentary processes; In: Geochemistry and Mineralogy of Rare Earth Elements (eds) Lipin B R and McKay G A, Rev. Mineral. 21 169-200.

McLennan S M, Taylor S R and Eriksson K A 1983 Geochemistry of Archean shales from Pilbara Supergroup, Western Australia; Geochim. Cosmochim. Acta $\mathbf{7 4}$ 1211-1222.

McLennan S M, Taylor S R, McCulloch M T and Maynard J B 1990 Geochemical and Nd-Sr isotopic composition of deep sea turbidites: Crustal evolution and plate tectonic associations; Geochim. Cosmochim. Acta $542015-2050$.

McLennan S M and Taylor S R 1991 Sedimentary rocks and crust evolution: Tectonic setting and secular trends; J. Geol. 99 1-21.

Mishra D C, Singh B and Gupta S B 2002 Gravity modeling across Satpura and Godavari Proterozoic belts: Geophysical signatures of Proterozoic collision zones; Curr. Sci. 83(8) 1025-1031.

Naqvi S M, Sawkar R H, Subba Rao D V, Govil P K and Rao T G 1988 Geology, geochemistry and tectonic setting of Archean greywacke from Karnataka nucleus, India; Precamb. Res. 39 193-126.

Paikaray S, Banerjee S and Mukherjee S 2008 Geochemistry of shales from the Paleoproterozoic to Neoproterozoic Vindhyan Supergroup: Implications on provenance, tectonics and paleoweathering; J. Asian Earth Sci. 32 $34-48$.

Pettijohn F J, Potter P E and Siever R 1972 Sand and Sandstone (Berlin: Springer-Verlag), $241 \mathrm{p}$.

Potter P E 1986 South America and a few grains of sand, Pt. I. Beach sands; J. Geol. 94(3) 301-319.

Rao K S, Lal C and Ghosh D B 1977 Algal stromatolites in the Bhander Group of formations, Vindhyan Supergroup, Satna District, Madhya Pradesh; Rec. Geol. Surv. India 109(2) 38-47.

Ray J S, Martin M W, Veizer J and Bowring S A 2002 U-Pb zircon dating and $\mathrm{Sr}$ isotope systematics of the Vindhyan Supergroup, India; Geology 30 131-134.

Roser B P and Korsch R J 1986 Determination of tectonic setting of sandstone-mudstone suites using $\mathrm{SiO}_{2}$ content and $\mathrm{K}_{2} \mathrm{O} / \mathrm{Na}_{2} \mathrm{O}$ ratio; J. Geol. 94(5) 635-650.

Roser B P and Korsch R J 1988 Provenance signature of sandstone-mudstone suites determined using discriminant function analysis of major element data; Chem. Geol. 67 119-139.

Schwab F L 1975 Framework mineralogy and chemical composition of continental margin type sandstone; J. Geol. 3 $487-490$

Singh I B 1976 Depositional environment of the Upper Vindhyan sediments in the Satna-Maihar area, Madhya Pradesh and its bearing on the evolution of Vindhyan sedimentation basin; J. Paleont. Soc. India 19 48-70.

Srivastava A P and Rajagopalan G 1988 F.T. ages of Vindhyan glauconitic sandstone beds exposed around Rawatbhata area, Rajasthan; J. Geol. Soc. India 32 $527-529$.

Taylor S R and McLennan S M 1985 The continental crust: Its composition and evolution; Blackwell Scientific Publications, $312 \mathrm{p}$. 